\begin{tabular}{cc}
\hline \hline 特集 & $\begin{array}{l}\text { マイクロデイセクション法を } \\
\text { 利用した疾患の遺伝子研究 }\end{array}$ \\
\hline \hline
\end{tabular}

順天堂医学 $46(4)$

p. 416 422 (2001)

\section{マイクロダイセクション法と 遺伝子診断**}

\title{
Tissue microdissection and molecular diagnosis
}

\author{
野口雅 之* \\ MASAYUKI NOGUCHI
}

悪性腫瘍の診断に染色体の欠失や特定の遺伝子異常所見を用いる際は正確に腫瘍細胞のみを解 析することが重要である.つまり悪性度の指標を正確に求めるのであれば, 解析したい部位に存 在する腫場細胞を正しく採取して, その遺伝子異常を解析することが求められるからである。こ の目的を可能にするような組織マイクロダイセクション法の技術が実用化されつつある。レー ザー光を利用した組織マイクロダイセクション法を中心に特定の細胞群を採取する方法論とこれ を利用した分子病理学について解説した.

具体例として組織マイクロダイセクション法を利用した遺伝子診断の例を4つあげた.

(1) 再発肺癌の遺伝子診断を細胞診材料を用いて行った。胸水細胞診材料中の異型細胞に扎け る p53 遺伝子や ras 遺伝子の点突然变異をPCR-SSCP法で解析することによって再発をより早期 に発見できることを示した。（2）臟器に複数の癌病巣が存在するとき, その起源が多中心性発 生か転移性かを明確に鑑別することは，その臓器癌の発癌過程を理解し，組織発生を解明するた めに重要である，前立腺癌を例にとって組織マイクロダイセクション法を利用した解析を示 した. (3) 卵巣内膜性囊胞と内膜癌や明細胞癌との関係をPTEN遺伝子領域の染色体欠失と点 突然変異を解析することによって検討した。そ結果PTEN遺伝子の不活化が卵巣内膜癌や明 細胞癌の発癌のごく初期に起こっていることを示し, 卵巣内膜症性囊胞からこれらの癌へ進展す る連続的な多段階発癌機構が存在することを示した（4）消化管リンパ腫の遺伝子診断（ミク 口の遺伝子診断の限界）を示した. リンパ滤胞の芽中心をマイクロダイセクション法にて解析す ると個々の芽中心について平均 2.4 から 2.5 個の再構成バンドが認められることを示した．この 結果は胃生検や大腸の生検でMALT typeのリンパ腫を診断する際には注意が必要であることを 示している.

$$
\begin{aligned}
\text { キーワード : レーザー光, クローン性, 再発肺癌, 前立腺癌, 卵巣子宮内膜性囊胞 } \\
\text { Key words : laser, clonality, recurrent lung cancer, prostate cancer, } \\
\text { ovarian endometriotic cyst }
\end{aligned}
$$

* 筑波大学基礎医学系病理学

Department of Pathology, Institute of Basic Medical Sciences, University of Tsukuba, Ibaraki, Japan $* *$ 第293 回順天堂医学会学術集会 [Sept. 21, 2000 開催] 〔Jan. 19, 2001 原稿受領〕

\section{はじめに}

診断学上，遺伝子解析は家族性大腸腺腫症や遺 伝性非ポリポーシス大腸癌などの家族性腫痬にお いては最も重要な検査であるが，その他，癌の悪 性度診断・多発癌・再発癌の診断等にも応用され 
つつある。しかし，一般に悪性腫瘍の診断に染色 体の欠失や特定の遺伝子異常所見を用いる際は， 胚細胞点突然変異解析などのように患者のいかな る部分の組織を対象にして遺伝子解析してもよい 場合と異なり，正確に腫瘍細胞のみを解析するこ とが重要である。なぜなら腫瘍組織は腫瘍細胞の 他にも多くの間質細胞（血管内皮細胞・線維芽細 胞など）を含んでいるからである.

発癌とは遺伝子学的に多段階に発生する事象で あり, 癌部と前癌病変部・原発巣と転移巣, そし て癌の内部においても, 腫瘍細胞はモノクローナ ルな集団とはいえない，固形癌に打いては分化度 の異なる病変が共存していることはよく認められ ることであるが，遺伝子学的にこれら分化度が異 なる腫瘍細胞群は異なった細胞集団であることが 証明される例もある。つまり悪性度の指標を正確 に求めるのであれば，解析したい部位に存在する 腫瘍細胞を正しく採取して，その遺伝子異常を解 析することが必要である。

近年上記の目的を可能にするような組織マイク ロダイセクション法の技術が実用化されつつあ る.以下, レーザー光を利用した組織マイクロダ
イセクション法を中心に特定の細胞群を採取する 方法論とこれを利用した分子病理学について解説 する。

\section{組織マイクロダイセクション法の比較}

マイクロダイセクションの方法は針・楊枝な ど，あるいはマイクロマニピュレーターを用いた マニュアル操作による方法とレーザー光を用いて 切除するマイクロダイセクション法の 2 群に大別 される。

後者の方法論によるPixcell ${ }^{\mathrm{TM}}$ system ( 以下 LCM ), Arcturus Engineering, Inc. ( http : //www. arctur. com ) とP.A.L. M. ${ }^{\text {TM }}$ LaserMicroscope-Systems ( 以下PALM ), P.A. L. M. GmbH (http : //www.PALM-Mikrolaser. com ) が代表的である. LCMとPALMはともにレーザー を用いているが，その原理は異なっており，LCM では標本に直接転写フィルムを接触させ，レーザー 光を照射するとその照射部のみがフィルムに転写 される.一方，PALMは細胞または目的部分の周 囲を破壊切断することで目的部を得る方法である.

表-1 レーザー光を利用した組織マイクロダイセクション法の比較

\begin{tabular}{|c|c|c|}
\hline & LCM & PALM \\
\hline レーザー光源 & 炭酸ガスパルスレーザー & 窒素パルスレーザー \\
\hline 波長 & $10 \mu \mathrm{m}$ & $337 \mathrm{~nm}$ \\
\hline レーザーのファーカス径 & $7.5 \mu \mathrm{m}$ 以上 & $0.1 \mu \mathrm{m}$ 以下 \\
\hline 切削方法 & 局所的な加熱による融解転写 & 高密度光子による非加熱破壊 \\
\hline サンプルの前処置 & 通常の薄切標本で可能 & $\begin{array}{l}\text { 薄切標本を特殊なフィルムに載 } \\
\text { せて染色の後に反転して切削す } \\
\text { るためやや煩雑である. }\end{array}$ \\
\hline レーザーの照射 & $\begin{array}{l}\text { 単発照射をくり返すため採取細 } \\
\text { 胞数が多いときには効率が悪い. }\end{array}$ & $\begin{array}{l}\text { 目的の細胞集団の周りを切断す } \\
\text { るため集塊が取りやすい. }\end{array}$ \\
\hline 操作性 & $\begin{array}{l}\text { モニタ画面の移動は通常通り } \\
\text { ステージで行う. } \\
\text { トリガー使用 }\end{array}$ & $\begin{array}{l}\text { モニタ画面の移動はパソコン上 } \\
\text { で行う. } \\
\text { フットスイッチ使用 }\end{array}$ \\
\hline 細胞の採取 & $\begin{array}{l}\text { 転写フィルムを直接バッファー } \\
\text { に接触させるためロスが少ない. }\end{array}$ & $\begin{array}{l}\text { 採取部をPCRチューブのキャッ } \\
\text { プ内に飛ばすため紛失の危険が } \\
\text { ある. }\end{array}$ \\
\hline 価格 & 比較的安価 & 比較的高価 \\
\hline
\end{tabular}


各方法の特徴を表-1にまとめた。いずれの方 法でも, 検体から DNA・RNA・タンパクの抽出 が可能であるが，もちろん検体の保存状態や標本 の作成方法の違いによって採取できる核酸・タン パクの変性度は異なっている，針・楊枝などを用 いたマイクロダイセクションは簡便で安価である が正確性に劣る。マイクロマニピュレーターを用 いた方法は細胞 1 個を採取することが可能で正確 な方法だが手技に熟練を要し，また検体採取まで に時間がかかるため，特にRNAの採取には不適 当である。LCM は簡便だが特殊な転写フィルム を購入する必要がある. PALM はLCM 同様正確 だが前処理が煩雑であり，標本作製にやや熟練を 要す.

しかしいずれの方法を選択するかについては， 得た検体でどのような遺伝子解析を行うかが最 も大事な要件となる. Loss of heterozygosity （LOH）をPCR-LOH 法により確認する場合に は目的の細胞群が検体の7割以上を占める必要が あるが，PCR-SSCP ( single strand conformation polymorphism ) 法などを用いて突然変異の スクリーニングをする場合にはPCR-LOH解析ほ どの正確さは要求されない。一方, RT-PCR法を 用いた遺伝子発現の解析には 10 個程度の細胞数 でもよいから正確な材料採取が必要だが, cDNA ライブラリーを作る場合には single cell を採取で きる正確さと 1000 個以上の細胞数を採取できる 簡便さを兼ね備えている必要がある。特にRNA やタンパクを検体とする場合にはDNAより迅速 な施行を要求されるため, 手技が簡便であるもの が好まれる。このように，採取した検体を何に応 用するかによってマイクロダイセクションの方法 は選択されるべきであろう1)2）。

\section{マイクロダイセクション法を利用した 病理診断の実例や分子病理学的解析例}

\section{1. 再発癌の遺伝子診断 ${ }^{3)}$}

同時性あるいは異時性の多発癌の遺伝子診断が 可能であるとすれば再発癌の遺伝子診断も同様な
方法論で可能である．特に今後遺伝子治療や陽子 線治療などの新しい治療法が効果を示すようにな ればなるほど第 2 次癌の診断とともに再発癌をで きるだけ早く確診することは患者の予後を改善す るために重要である。そこで胸水からの細胞診材 料を利用して肺癌の再発の遺伝子診断を試みた. 肺癌はしばしば悪性胸水として再発する。この再 発診断を少数の胸水中の癌細胞から確診できれ ば，再発に対する治療をより早く開始できる。そ こで細胞診材料を利用した遺伝子解析を癌の再発 の早期診断に応用する可能性を検討した。用いた 症例は16例の肺癌切除後悪性胸水で再発した例で ある。この中には2例の多重癌も含まれている.

用いた方法は前述したPCR-SSCP 法とDNA シークエンス法を組み合わせて癌抑制遺伝子であ る p53 と癌遺伝子である K-ras の突然変異を解析 しこれをマーカーにして切除材料の異常と再発細 胞診のそれとを比較した（図-1).p53のSSCP 解析には exon 45678 の各exonを, K-rasの解 析にはexon 1を用いた。切除材料についてはホル マリン固定後パラフィン包埋ブロックの薄切標本 から, 細胞診材料については診断に用いた細胞診 材料のカバーガラスをはがして乾燥させた標本か ら, 組織細胞マイクロダイセクション法にて腫瘍

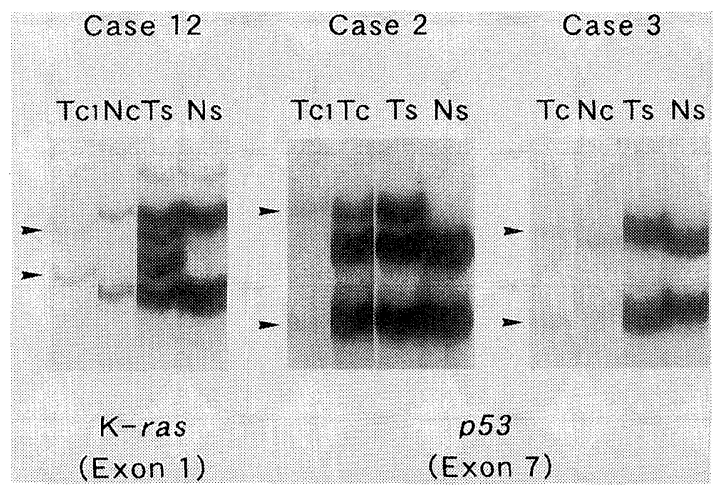

図-1 手術切除検体と同一の再発細胞診検体を用い たK-rasとp53遺伝子のPCR-SSCP解析

矢頭に異常バンドを認める。 $\mathrm{N}$ ：正常組織, Ts：手術 的に切除した腫瘍, Tc：再発腫瘍細胞 (細胞診材料), Tc1：再発腫瘍細胞 ( single cell). (文献 3) より引用) 
細胞と診断された異型細胞を採取してここから DNAを抽出し，これらを解析に用いた，得られた 異常バンドについては核酸の塩基配列も決定した. まず手術的に切除された原発癌について解析する とp53遺伝子については6つの異常バンドが, K-ras 遺伝子については 1 つ異常バンドが検出され た.p53遺伝子のexon 7 の異常が4例に, exon 4 と 5 の異常が 2 例に, exon 7 と K-ras 遺伝子の exon 1 の異常をともに持つ症例が 1 例見つかった。

一方, 細胞診材料から採取されたDNAを用い た解析では合計 $5 つ の$ 異常バンドが検出され，こ れらは手術材料で検出された異常バンドのうちの 5つと同じサイズのものであった。これらの異常 バンドが手術材料から得られた異常バンドと同じ 核酸塩基配列を有することを確認するためにその 塩基配列を解析した. 5 つのバンドのうち 4 つは ミスセンス変暴であり，1つはサイレント変異で あった.これらの変異は手術材料・細胞診材料で 一致した。しかしながら, 手術材料で検出された 2 症例で見つかったp53 遺伝子の exon 4 と 7 の異 常は細胞診材料では検出できなかった。以上の結 果より, 解析した 16 例のうち4例については遺伝 子学的にも再発であることが確認できた．細胞診 で同じ異常を見つけられなかった 2 症例について は胸水中に出現した細胞が別の癌であった可能 性, 原発部の腫瘍が遺伝子学的にへテロが集団で たまたま p53 遺伝子異常を持たない成分が再発し てきた可能性, 細胞診材料での診断が overdiagnosisであった可能性などが考えられる.

以上のような不一致例の正しい解釈は多くの症 例にこの診断法を応用していくうちに明らかになっ てくると考えられる。いずれにしても細胞診材料 は腫瘍の再発診断には日常的に用いる重要な形態 診断であり，かつアルコール固定であるので核酸 の保存が良くホルマリン固定した組織材料より遺 伝子解析に適しているという利点がある。原発例 の遺伝子解析が十分になされていれば細胞診材料 で同じ遺伝子異常を確認することによって再発の 遺伝子診断が可能であることを示した。
2. 前立腺癌は多発し易い癌なのか腺内転移し易 い癌なのか4）

臓器に複数の癌病巣が存在するとき, その起源 が多中心性発生か転移性かを明確に鑑別すること は, その藏器癌の発癌過程を理解し, 組織発生を 解明するために重要である. 組織マイクロダイセ クション法を用いた遺伝子解析をするといままで 解釈がまちまちであった事象がより正確に評価で きるようにもなる，たとえば前立腺癌はそのほと んどが腺癌であり, 前立腺癌の特徴の一つとして 切除材料を用いた病理学的観察をすると同一腺内 に複数の腫瘍結節を認めることが多いことがあげ られる. 組織マイクロダイセクション法を用いて これら多結節腫瘍からそれぞれ腫瘍細胞を分離し て採取することが可能になってきた。試みに採取 された少数の癌細胞から DNAを抽出して前立腺 癌で報告の多い染色体欠失のパターンを比較検討 することによってこれら多結節腫瘍が多中心性の 癌なのか, 一つの前立腺癌の腺内転移なのかを解 析してみた. 前立腺癌では種々の染色体が欠失し ていることが報告されているが，中でも $3 \mathrm{p}$ ・ $7 \mathrm{q} \cdot 8 \mathrm{p} \cdot 10 \mathrm{q} \cdot 16 \mathrm{p} \cdot 17 \mathrm{q} \cdot 18 \mathrm{q}$ などに頻度が高 い.そこで 25 症例の全摘された前立腺腫瘍組織 から 63 の異なった組織型を示す場所を選んで, 組織マイクロダイセクション法により腫瘍細胞の みを採取した。

調べた染色体の部位は3p (D3S647・D3S1228) $\cdot 7 \mathrm{q}(\mathrm{D} 7 \mathrm{~S} 522) \cdot 8 \mathrm{p}(\mathrm{D} 8 \mathrm{~S} 137 \cdot \mathrm{NEFL}) \cdot 10 \mathrm{q}$ （D10S190）の6箇所である。検索した染色体部 位のいずれかに欠失を認めた症例は 10 例あり， そのうち8例は同一腺内の組織型の異なる部位で その染色体欠失のパターンが異なっていることが わかった（図-2）。異なる組織型を示す結節ごと に染色体の欠失のパターンが異なること, また解 析症例の中には通常悪性度がより高いと考えられ る低分化部に染色体欠失が認めないのに，高分化 や中分化部に認める症例もあった。この事実は腺 内転移によって染色体の欠失が加算されたとも考 えにくい.むしろ組織型によって久失のパターン が異なることは，それぞれの欠失が異なったク 
B: $N$ P

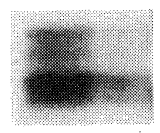

NEFL

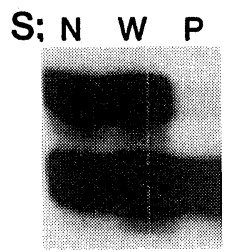

NEFL
B : biopsy specimen, $\mathrm{S}:$ resected specimen,

$\mathrm{N}:$ non-tumorous region, $\mathrm{W}:$ well differentiated,

$\mathrm{M}$ : moderately differentiated, cap : capsular invasion,

$\mathrm{P}$ : poorly differentiated

図-2 前立腺癌の LOH解析

手術材料にはへテロな組織型が認められ，LOHのパ ターンが異なる。（文献 4）より引用）
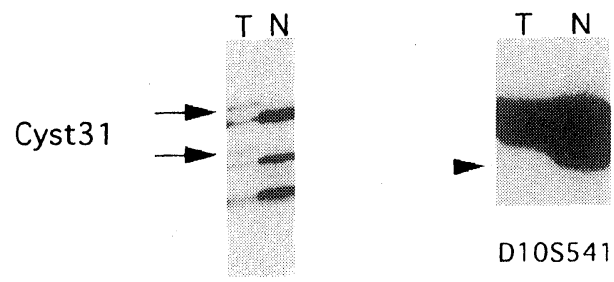

図-3 卵巣子宮内膜囊胞に見い出されたPTEN遺伝 子領域の LOH と PCR-SSCP解析で見つけら れた異常バンド

$\mathrm{T}$ ：卵巢子宮内膜囊胞, $\mathrm{N}$ ：正常子宮内膜.

(文献 5）より引用)

ローンから構成されていることを示していると解 釈される，以上より前立腺癌にしばしば認められ る同一腺内の多結節病変は一つの腫痬の転移では なく, むしろ多中心性の多発腫瘍と解釈すべきで あることがわかる.

この事実はこれから近い将来にそれぞれの染色 体欠失の生物学的意味づけが明らかになってき て，この知見を利用した遺伝子診断が実用化され たとしても腫瘍のごく一部しか採取しない針生検 材料の遺伝子解析では腫瘍全体の遺伝子学的悪性 度を正しく評価することは難しいことも示唆して いる。事実，前述した症例の針生検例では，検体 の組織型は低分化腺癌でNEFLの欠失が認められ るが，欠失を持たない高分化腺癌は採取されてい
ないので,この存在は生検では診断できていない. 3. 卵巣内膜性囊胞は内膜癌や明細胞癌の前癌病 変を言えるか5

チョコレート襄胞は卵巣明細胞腺癌・類内膜腺 癌の約 3 割と共存し, またチョコレート囊胞の管 理中に癌化する確率も 0.7 ～1.0\%あると言われ ている。一方，婦人科腫瘍に打いては子宮内膜 癌・卵巣類内膜腺癌で癌抑制遺伝子 PTENに約 $40 \%$ と高頻度の突然変異を認めることが知られ ている。そこで卵巣類内膜腺癌の前癌病変と考え られるチョコレート襄胞における異所性内膜の PTEN 遺伝子異常を組織マイクロダイセクション 法を利用して検討した。

チョコレート襄胞は間質を伴った異所性内膜を 内腔に有するが内膜は一層であり，この異所性内 膜細胞を正確に採取するためにLCM 用いた。 LCM で採取した 8 細胞相当から抽出したDNA を用いて，D10S541・D10S215・D10S608の PTEN 遺伝子領域の 3 カ所のマイクロサテライト 多型を利用してPCR-LOH 法にて 10 番染色体長腕 のPTEN 領域の染色体欠失を解析した（図-3). また, PTEN遺伝子の突然変異についてはPCRSSCP法にて認められたシフトしたバンドから PCR産物を抽出し，これに対してクローニング シークエンス法を行いその核酸塩基配列を決定し た。用いた症例は 20 例の卵巣内膜癌, 24 例の卵 巣明細胞癌, そして 34 例のチョコレート囊胞で ある.10q23.3 領域の LOH は卵巣内膜癌で $42.1 \%$ に，明細胞癌で $27.3 \% に$ 見つかったが，チョコ レート豪胞でも $56.5 \%$ という高率にLOHが発見 された. PTEN遺伝子の点突然変異も卵巣内膜癌

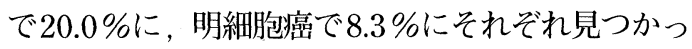
たが，チョコレート囊胞でも $20.6 \%$ 症例に点 突然変異が認められた。これらの結果はPTEN遺 伝子の不活化が卵巣内膜癌や明細胞癌の発癌のご く初期に起こっていることを示し，卵巣内膜症性 囊胞からこれらの癌へ進展する連続的な多段階発 癌機構が存在することを示している. 


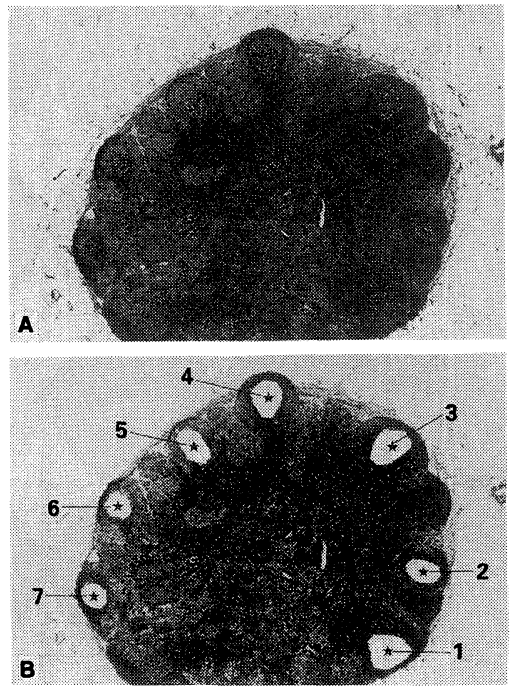

図-4 反応性リンパ節の芽中心から組織マイクロダ イセクション法にて標本を採取する

（文献 6）より引用）

4. 消化管リンパ腫の遺伝子診断 (ミクロの遺伝 子診断の限界 ) 6 )

マイクロダイセクションを用いた解析の利点は 少数細胞を用いた解析が可能であることにある が，注意すべき点もある．たとえば，われわれは B 細胞性の悪性リンパ腫の補助診断としてイムノ グロブリン遺伝子の重鎖の再構成の有無を用いる が，微小検体に対してPCR反応を用いた解析を 行うと偽陽性の結果を得ることがある。試みにリ ンパ濾胞の芽中心をマイクロダイセクション法に て多数採取して 2 つプライマーセットでseminested PCRを行いイムノグロブリン重鎖の再構 成を検索してみると 28 個の芽中心を解析して 67 から 71 の再構成バンドを認めた（図-4，-5)。つ まりその結果はスメアーパタンを示さず, 個々の 芽中心について平均 2.4 から 2.5 個の再構成バン ドが認められることになる。実際シングルバンド として認める牙中心は 28 個中 4 から5個 (16\%) 存在していることがわかった.

この結果は胃生検や大腸の生検で MALT type のリンパ腫を診断する際には注意が必要であるこ

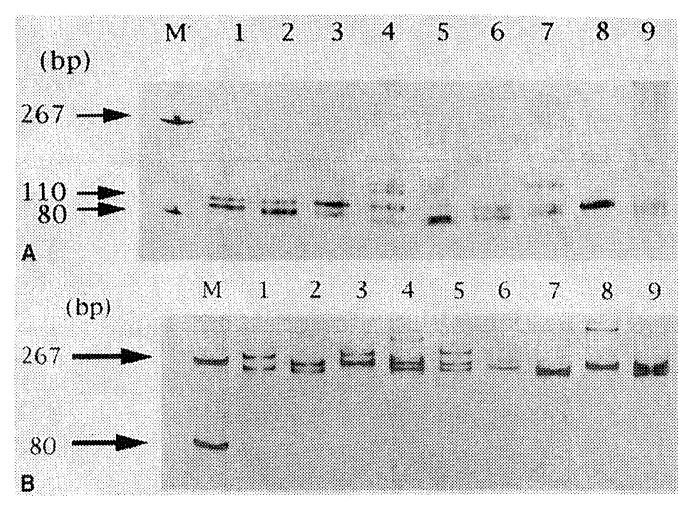

図-5困-4で得られたDNAをテンプレイトにした イムノグロブリン重鎖の nested-PCR解析

$\mathrm{A}$ ：プライマーとしてFR3Aを用いた場合, B：プライ マーとしてFR2Aを用いた場合，M：サイズマーカー， 数字は図-4の部位に対応する.9：リンパ節すべてから 採取したDNA.（文献 6) より引用）

とを示している。形態学的に明らかに慢性胃炎, あるいは非特異性大腸炎と診断されたそれぞれ 19 例・25例の生検材料を材料としてイムノグロ ブリン重鎖の再構成を上記のnested PCR法を用 いて検索するとそれぞれ3例 $(21.1 \% \cdot 16 \%) に$ シングルバンドを検出した。 このように微小材料 を用いた検索をする際は偽陽性を見ている可能性 があることを念頭にいれて注意深い検討が必要で ある。

\section{おわりに}

組織マイクロダイセクション法の原理を示し, これを用いた病理学的解析をいくつか紹介した。 病変組織全体から抽出した核酸を用いた遺伝子解 析が，いわばマクロの遺伝子解析とするなら, 組 織マイクロダイセクション法を用いた遺伝子解析 はミクロの遺伝子解析ということができる。形態 学的知見と分子生物学的知見とを有機的に結びつ けた病理診断を行えばより疾患の本質にせまる診 断がなされるのは明らかであり, 組織マイクロダ イセクション法を利用したミクロの分子病理学の 重要性がますます増してきた。 


\section{文献}

1) 佐藤奈加子, 青柳靖之, 野口雅之：Laser assisted microdissection法を中心とした組織局所 の遺伝子診断. 病理と臨床, $2000 ; 18 ： 624$ 627.

2 ) 瀧本泰彦, 野口雅之: 多重癌・再発癌の遺伝子 診断. 病理と臨床, $2000 ; 18: 666 \sim 671$.

3) Dai Y, Morishita Y, Mase K, et al. : Application of the p53 and K-ras gene mutation patterns for cytologic diagnosis of recurrent lung carcinomas. Combined analysis with microdissection and polymerase chain reaction-single-strand conformation polymorphysm. Cancer ( Cancer Cytopatho1 ), $2000 ; 90: 258 \sim 263$.

4) Takimoto Y, Shimazui T, Akaza H, et al. : Genetic heterogeneity of surgically resected prostate carcinomas and their biopsy specimens is related to their histologic differentiation. Cancer, $2001 ; 91: 362 \sim 370$.

5 ) Sato N, Tsunoda H, Nishida M, et al. : Loss of heterozygosity on 10q23.3 and mutation of the tumor suppressor gene PTEN in benign endometrial cyst of the ovary : Possible sequence progression from benign endometrial cyst to endometiroid carcinoma and clear cell carcinoma of the ovary. Cancer Res, $2000 ; 60: 7052 \sim$ 7056 .

6) Iijima $T$, Inadome $Y$, Noguchi M : Clonal proliferation of B lymphocytes in the germinal centers of human reactive lymph nodes : Possibility of overdiagnosis of B cell clonal proliferation. Diagn Mol Pathol, 2000 ; $9:$ 132 136. 